Diabetologia (1994) 37: 49-55

\title{
Betel nut (Areca catechu) consumption and the induction of glucose intolerance in adult CD1 mice and in their F1 and F2 offspring
}

\author{
B.J.Boucher ${ }^{1}$, S. W. B. Ewen ${ }^{2}$, J.M.Stowers ${ }^{2}$ \\ ${ }^{1}$ Cellular Mechanisms Research Group, London Hospital Medical College, London, UK \\ ${ }^{2}$ Department of Pathology, Aberdeen Royal Infirmary, Aberdeen University, Aberdeen, UK
}

Summary Many mutagenic nitroso compounds are also diabetogenic. Betel-nut (Areca catechu) chewing populations have an increased incidence of foregut cancers related to betel-nut nitrosamines which suggests that betel consumption could be diabetogenic. Young adult CD1 mice with a low spontaneous incidence of diabetes were fed betel nut in standard feed for 2-6 days. Single point ( $90 \mathrm{~min}$ ) intra-peritoneal glucose tolerance tests were used to follow glucose tolerance up to 6 months of age. Glucose intolerance was defined as over $3 \mathrm{SD}$ above mean control values. Glucose intolerance was found in 3 of 51 male and 4 of 33 female adult mice which were fed the betel diet $(p<0.01)$. Studies on the progeny of these mice are presented separately for animals studied in Aberdeen (Group 1) and London (Group 2). In matings of Group 1 betel-fed parents glucose intolerance was found in 4 of 25 male and 1 of 22 female F1 offspring, with significant hyperglycaemia in F1 males born to hyperglycaemic but not to normoglycaemic mothers $(p<0.01)$. In the $\mathrm{F} 2$ generation 4 of 23 males and 1 of 16 females and in the F3 generation 1 of 16 males and 0 of 20 females were glucose intolerant. In the Group 2 studies where betel-fed parents were mated to normal controls glucose intolerance was found in 10 of 35 male and 10 of 33 female $\mathrm{F} 1$ progeny $(p<0.005)$, and mean islet areas were increased in offspring of betel-fed parents $(p<0.001)$. The total incidence of glucose intolerance in F1 progeny from studies in Groups 1 and 2 was 14 of 60 males and 11 of 55 females $(p<0.005)$. Insulin dependence did not develop in the glucose-intolerant betel-fed animals or their descendants; affected animals appearing well built and active. The development of glucose intolerance in F1 offspring was not dependent on maternal glucose intolerance or on maternal betel-feeding, and 90-min glucose levels of F1 offspring were directly related to paternal but not to maternal glycaemia $(p<0.01)$. Our findings suggest that betelnut (Areca) consumption may be diabetogenic and induce an inheritable abnormality. The hypothesis is of interest in view of the widespread habit of betel consumption and of the strategies known to inhibit the induction of experimental diabetes by diabetogenic nitroso compounds. [Diabetologia (1994) 37: 49-55]

Key words Diabetes mellitus, nitrosamines, nitrosocompounds, Areca catechu, Betel nut, inheritance
The prevalence of Type 2 (non-insulin-dependent) diabetes mellitus in Asians who have migrated from Bangladesh to the United Kingdom over the last 30 years is high, as it is in other immigrant Asian groups

Received: 25 January 1993

and in revised form: 29 July 1993

Corresponding author: Dr. B. J. Boucher, The Medical Unit, The Royal London Hospital, Whitechapel Road, London E11BB, UK
$[1,2]$. This is not due simply to an increase in Western life styles since an equally high prevalence has been found in some groups of Asians in Fiji and in India, both in towns and in certain rural areas [3,4]. It has also been noted that Asians with Type 2 diabetes living in the United Kingdom require insulin at a much younger age than Type 2 diabetic Caucasians [5]. The prevalence of Type 2 diabetes in the Asian immigrant population has not begun to decline towards that of the indigenous population of the United Kingdom. In addition to possible genetic factors, this community may 
Table 1. Results of intra-peritoneal glucose tolerance tests on Group 1 Control and betel-fed CD-1 mice and their offspring

\begin{tabular}{|c|c|c|c|c|c|}
\hline & & Sex & $n$ & $\begin{array}{l}90 \text {-min plasma glucose }(\mathrm{mmol} / \mathrm{l}) \text {. } \\
\text { Mean } \pm \text { SD (range) }\end{array}$ & $n$ with IGT \\
\hline \multirow[t]{2}{*}{ Adults } & Control & $\begin{array}{l}\text { Male } \\
\text { Female }\end{array}$ & $\begin{array}{r}126 \\
86\end{array}$ & $\begin{array}{r}8.8 \pm 2.46(3.0-16.05) \\
6.16 \pm 1.58(2.45-12.1)\end{array}$ & $\begin{array}{l}0 \\
1\end{array}$ \\
\hline & Betel fed & $\begin{array}{l}\text { Male } \\
\text { Female }\end{array}$ & $\begin{array}{l}27 \\
18\end{array}$ & $\begin{array}{l}9.86 \pm 3.0(5.18-20.3) \\
7.96 \pm 3.89(3.8-17.5)^{\mathrm{b}}\end{array}$ & $\begin{array}{l}1 \\
3\end{array}$ \\
\hline \multicolumn{6}{|l|}{ F1 Offspring } \\
\hline $\begin{array}{l}\text { Parentage } \\
\text { Mother }\end{array}$ & Father & & & & \\
\hline Betel +, IGT - & Betel + , IGT + & $\begin{array}{l}\text { Male } \\
\text { Female }\end{array}$ & $\begin{array}{l}3 \\
4\end{array}$ & $\begin{array}{l}17.4 \pm 5.5(13.2-26.1)^{\mathrm{b}} \\
7.85 \pm 0.55(7.3-8.6)^{\mathrm{a}}\end{array}$ & $\begin{array}{l}2 \\
0\end{array}$ \\
\hline Betel,+ IGT + & Betel,+ IGT - & $\begin{array}{l}\text { Male } \\
\text { Female }\end{array}$ & $\begin{array}{l}5 \\
3\end{array}$ & $\begin{array}{c}11.3 \pm 0.87(10.2-12.5)^{b} \\
6.5 \pm 0.64(6.0-7.2)\end{array}$ & $\begin{array}{l}0 \\
0\end{array}$ \\
\hline \multirow[t]{3}{*}{ Betel,+ IGT -} & $\begin{array}{l}\text { Betel }+, \text { IGT - } \\
\text { 1st litter }\end{array}$ & $\begin{array}{l}\text { Male } \\
\text { Female }\end{array}$ & $\begin{array}{l}6 \\
5\end{array}$ & $\begin{array}{l}6.4 \pm 0.62(5.5-7.4) \\
5.6 \pm 0.7(4.6-6.55)\end{array}$ & $\begin{array}{l}0 \\
0\end{array}$ \\
\hline & 2nd litter & $\begin{array}{l}\text { Male } \\
\text { Female }\end{array}$ & $\begin{array}{l}5 \\
5\end{array}$ & $\begin{array}{l}9.9 \pm 3.2(7.15-14.45) \\
5.9 \pm 0.78(4.7-6.8)\end{array}$ & $\begin{array}{l}0 \\
0\end{array}$ \\
\hline & 3rd litter & $\begin{array}{l}\text { Male } \\
\text { Female }\end{array}$ & $\begin{array}{l}3 \\
1\end{array}$ & $\begin{array}{l}17.3 \pm 7.9(10.9-26.1) \\
11.1\end{array}$ & $\begin{array}{l}1 \\
1\end{array}$ \\
\hline \multirow[t]{2}{*}{ Control } & Betel +, IGT + & $\begin{array}{l}\text { Male } \\
\text { Female }\end{array}$ & $\begin{array}{l}3 \\
4\end{array}$ & $\begin{array}{l}15.9 \pm 4.3(13.2-24.6)^{\mathrm{a}} \\
7.85 \pm 0.55(7.3-8.6)^{\mathrm{a}}\end{array}$ & $\begin{array}{l}1 \\
0\end{array}$ \\
\hline & All F1 offspring & $\begin{array}{l}\text { Male } \\
\text { Female }\end{array}$ & $\begin{array}{l}25 \\
22\end{array}$ & $\begin{array}{r}11.72 \pm 4.96(5.5-26.1)^{\mathrm{a}} \\
6.86 \pm 1.48(4.6-11.1)^{2}\end{array}$ & $\begin{array}{l}4 \\
1\end{array}$ \\
\hline
\end{tabular}

${ }^{\mathrm{a}} p<0.01 ;{ }^{\mathrm{b}} p<0.001 ; p=\mathrm{NS}$ for all other comparisons

Betel +, Betel-fed (2-8 days); IGT + , impaired glucose tolerance defined as 90-min plasma glucose $>3 S \mathrm{~S}$ above mean control levels

therefore have brought active aetiological agents for diabetes with them.

The increased mortality from oral and oesophageal cancer in many Asian communities, including those who have immigrated to the United Kingdom, is believed to be due to nitrosamines formed after chewing betel nut [6] whether plain or wrapped into a piper betel leaf 'quid'. This habit persists as is evident from mouth staining and the widespread availability of Areca nuts in local shops in the Tower Hamlets area of the east end of London. There is good evidence that certain nitrosamines and nitrosamides are diabetogenic in animals and in man, including the wellknown diabetogenic agent streptozotocin (STZ) and the rat poison Vacor. These agents provoke Type 1 (insulin-dependent) diabetes after single large doses whilst both induce Type 2 diabetes at lower doses as does STZ in rats if given within 2 days of birth [7, 8]. Specific nitrosamines from Icelandic smoked mutton, which may be diabetogenic in man, induce diabetes in the offspring of CD1 mice fed before mating [9]. Since nitrosamines are present in betel nut and also formed after ingestion (from Arecal alkaloids), the possibility that betel consumption might be diabetogenic and contribute to the increased prevalence of Type 2 diabetes found in Asians warranted investigation. This report describes a study in the mouse as part of a larger investigation of the hypothesis [10].

\section{Materials and methods}

Adult CD1 (random bred) mice as used in earlier studies with Icelandic smoked cured mutton [9] because of their low spontaneous incidence of diabetes $(<0.05 \%)$ were obtained from Charles River Co. (Manston, Kent, UK). The incidence of diabetes in control animals studied in Aberdeen (Group 1) was $0 \%$ in male and $1.2 \%$ in female mice and in animals studied in London (Group 2) it was $0 \%$. Only mice confirmed as having a normal intraperitoneal glucose tolerance test (IPGTT) at age 68 weeks were used for feeding experiments and subsequent breeding. The normal feed was Rat and Mouse 1 (RM1) pellets (SDS, Witham, Essex, UK) low in nitrosamines at under $0.2 \mu \mathrm{g} / \mathrm{kg}$ [9]. Areca catechu (betel nut) was purchased locally and ground to a powder for incorporation into feed for Group 1 at $30 \%$ in pure corn starch biscuits (Boots Pharmaceuticals, Nottingham, UK) and for Group 2 at $20 \%$ into reconstituted RMI pellets. These feeds were given on alternate days over 4-12 days (Group 1), or pair-fed for 5 consecutive days (Group 2), i.e. fed for 2-6 days, much as in the earlier work with smoked mutton [9].

Adult mice fed RM1 pellets throughout the study were used as controls for Group 1 mice and follow-up glucose tolerance studies were carried out on 2-3 occasions from 10 days to 12 weeks after completion of test feeding. Reconstituted RM1 pellets without betel were pair-fed to control Group 2 mice during test feeding at age $4-6$ weeks and glucose tolerance re-assessed on 2-3 occasions at age 12-24 weeks. Eight animals in Group 2 were fed betel nut similarly but with added $\beta$-carotene, known to reduce damage to DNA in human betel chewers [11], at $15 \mathrm{mg}$ per $100 \mathrm{~g}$ of feed. Breeding commenced 14 days after the end of test or pair-test feeding. The glucose tolerance of F1 offspring has been followed from 7-24 weeks, 
Table 2. Results of intramperitoneal glucose tolerance tests in Group 2 control and betel-fed CD1 mice and their F1 offspring

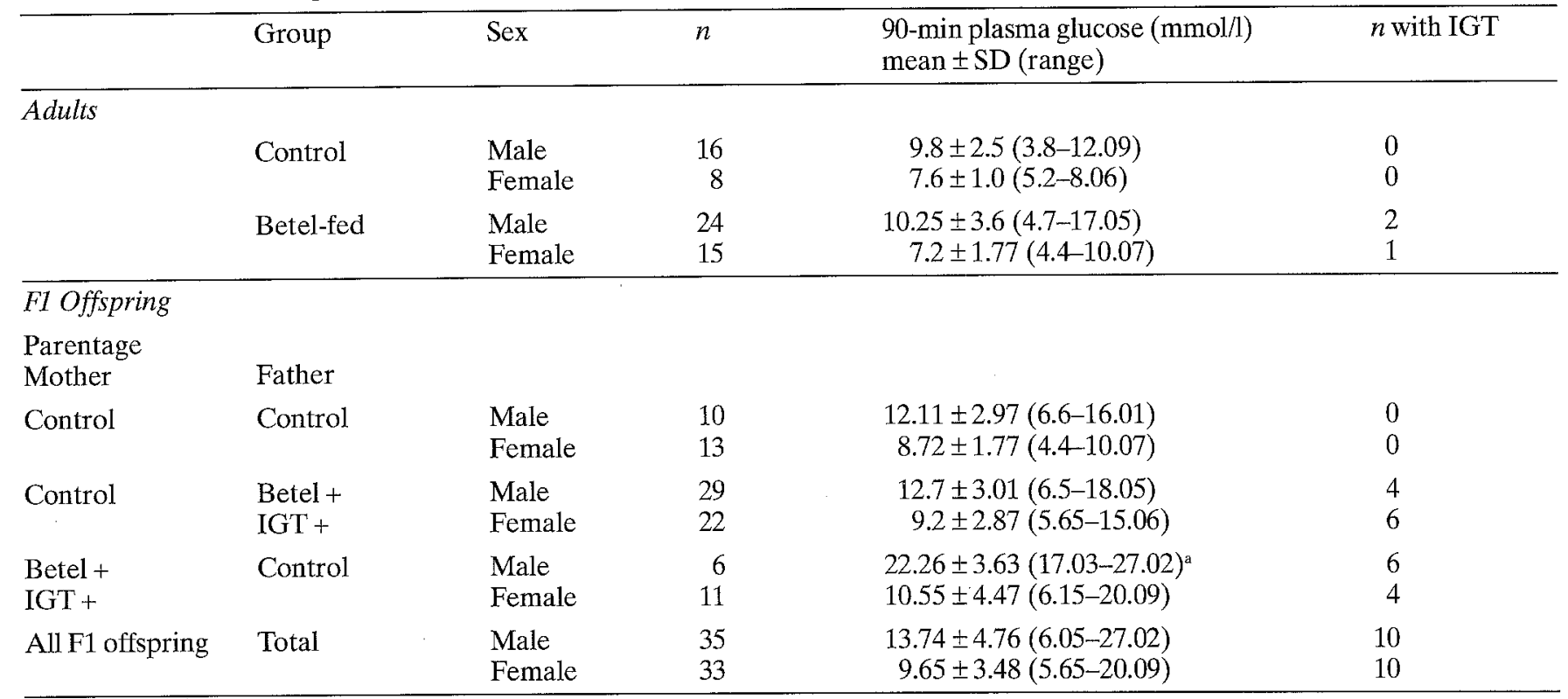

${ }^{a} p<0.001 ; p=$ NS for all other comparisons of mean 90-min plasma glucose levels in test vs control groups

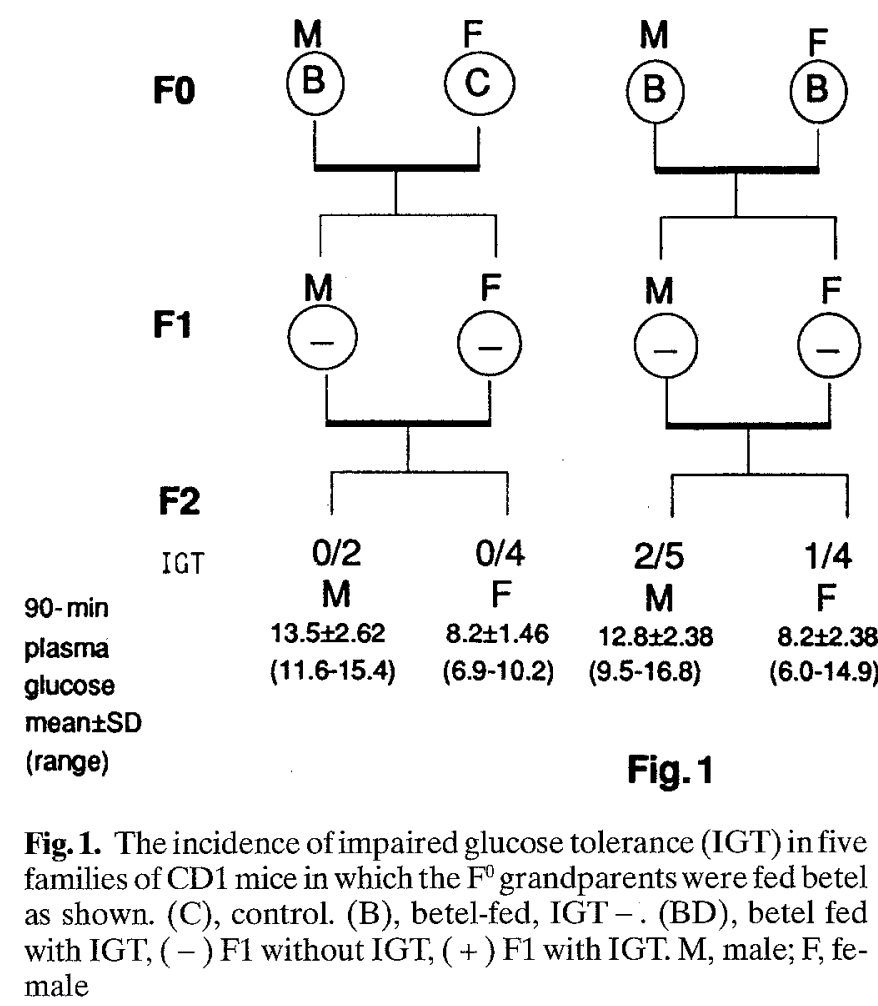

and of second and third generation litters for up to 3 months in Group 1 animals. Glucose tolerance has been assessed on two occasions up to 24 weeks of age in F1 offspring of Group 2 animals.

Glucose tolerance was assessed by IPGTT, as previously described [9], using $0.1 \mathrm{ml} / \mathrm{g}$ body weight of $20 \%$ glucose in $0.9 \%$ $\mathrm{NaCl}$ i.p. after an 18-h overnight fast (water ad libitum), with blood sampling at $90 \mathrm{~min}$. Initial studies showed that fasting plasma glucose levels were not significantly raised in glucose in-

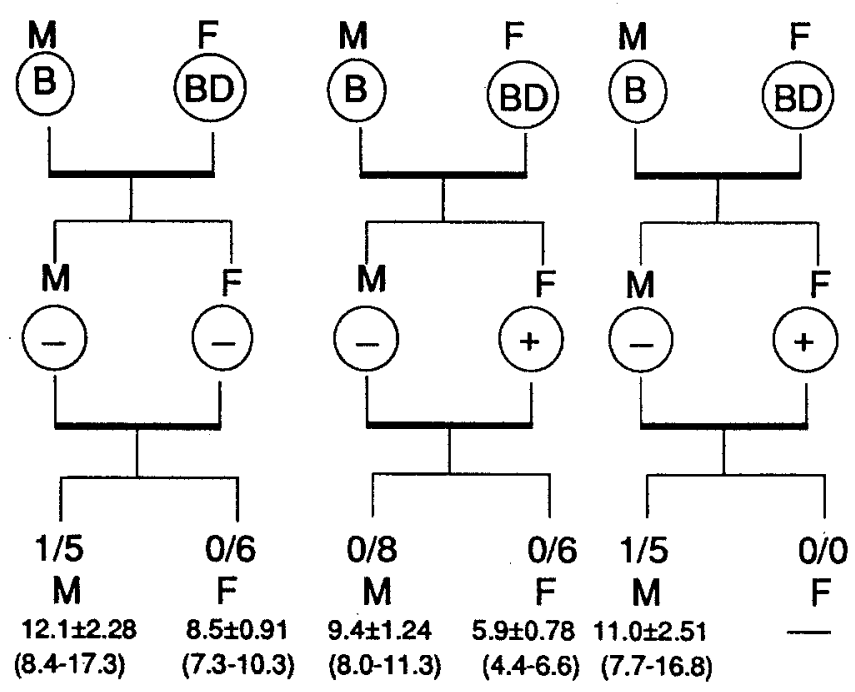

tolerant animals, as was found in feeding studies with smoked cured mutton [9]. All studies therafter used single point $90 \mathrm{~min}$ sampling IPGTT's. The plasma glucose levels given are the average of duplicate measurements using a Beckman glucose analyser; coefficient of variation $1.8 \%$ at $4.65 \mathrm{mmol} / 1,1.9 \%$ at $9.76 \mathrm{mmol} / 1$ for Group 1 and $2.1 \%$ at $8.22 \mathrm{mmol} / 1,2.05 \%$ at $11.8 \mathrm{mmol} / 1$ for Group 2; triplicate measurements were made whenever possible and especially for higher levels. Significantly impaired glucose tolerance (IGT) was diagnosed by $90-\mathrm{min}$ blood glucose levels more than 3.0 SD above the mean 90-min blood glucose level for the relevant control animals, i.e. at over $16.18 \mathrm{mmol} / \mathrm{l}$ in males and over $10.9 \mathrm{mmol} / \mathrm{l}$ in females in Group 1 (mean normal 90-min levels $8.8 \mathrm{mmol} / \mathrm{l}$ (SD 2.46) in 126 males and 6.16 (SD 1.38) in 86 females), and for Group 2 mice at over $15.8 \mathrm{mmol} / \mathrm{l}$ in males and over $10.6 \mathrm{mmol} / \mathrm{l}$ in $\mathrm{fe}-$ males (mean normal 90-min levels $9.8 \mathrm{mmol} / \mathrm{l}$ (SD 2.0) in 40 males and $7.6 \mathrm{mmol} / \mathrm{l}$ (SD 1.0) in 23 females). Histological 
examination of pancreatic tissue from Group 2 adults and offspring with and without IGT was carried out after standard staining with haematoxylin and eosin of a randomly-selected section through the length of each gland. Planimetry of every islet seen in one such section from each of 84 animals killed aged 6 months in Group 2 (randomly selected and blinded by an independent worker before measurement) was carried out with a Magiscan image analysis system (Applied Imaging, Sunderland, UK) using standard histomorphometric techniques [12]. Group 1 mice were not examined in significant numbers as they were in use for breeding. Measurements made included the areas of the islets with and without the acinar

Table 3. Incidence of impaired glucose tolerance (IGT) in control and betel-fed CD1 mice and their F1 offspring

\begin{tabular}{lll}
\hline Group & Male & Female \\
\hline Adults (Groups 1+2) & $0 / 142$ & $1 / 94$ \\
Control & $3 / 51^{\mathrm{b}}$ & $4 / 33^{\mathrm{b}}$ \\
Betel fed & & \\
F1 Litters Group 1 & - & - \\
of control mice & $4 / 25^{\mathrm{a}}$ & $1 / 22$ \\
of Betel-fed mice & & \\
F1 Litters Group 2 & $0 / 10$ & $0 / 13$ \\
$\begin{array}{l}\text { of control mice } \\
\text { of Betel-fed mice }\end{array}$ & $10 / 35^{\mathrm{a}}$ & $10 / 33^{\mathrm{a}}$ \\
$\begin{array}{l}\text { F1 Litters (Groups 1+2) } \\
\text { of control mice }\end{array}$ & & \\
of any Betel-fed parent & $0 / 10$ & $0 / 13$ \\
\hline
\end{tabular}

${ }^{\mathrm{a}} p<0.005,{ }^{\mathrm{b}} p<0.025, p=\mathrm{NS}$ for all other Chi-square tests, corrected for continuity, on incidence of IGT in test compared with control group tissue. The percentage of islet tissue and the numbers of islets per unit area of pancreas were then determined, as well as islet area per gramme body weight.

\section{Statistical analysis}

Statistical analyses included Chi-square tests (corrected for continuity) and Standardized Incidence Ratios (with $95 \%$ confidence limits) for the incidence of IGT and Student's two-tailed $t$-tests of the differences between mean blood glucose levels [13].

\section{Results}

All adult mice studied were non-diabetic before feeding experiments began, as determined by the initial IPGTT. Tables 1 and 2 show the incidence of IGT 2 to 24 weeks after completion of test feeding for 2-6 days. IGT was present in 1 of 27 male and 3 of 18 female betel-fed Group 1 and 2 of 24 male, 1 of 15 female Group 2 betel-fed mice, and 0 of the 8 mice fed betel and $\beta$-carotene. The incidence of IGT in betel-fed adults was significant $\left(\chi^{2 \mathrm{c}}=5.1\right.$ for males; $p<0.025$ and $\chi^{2 \mathrm{c}}=5.2$ for females; $\left.p<0.025\right)$. The Standardized Incidence Ratio (SIR) for IGT in the adults (Groups 1 and 2 ) was 1.95 (95\% confidence interval 1.62-2.44).

IGT was found in 3 of 6 male offspring of Group 1 betel-fed fathers with IGT when the mother was either betel fed but normoglycaemic or normal and non-betel fed (Table 1). When both betel-fed parents were nor-

Table 4. Histomorphometry of pancreas in betel-fed and control mice and their F1 offspring

\begin{tabular}{|c|c|c|c|c|c|c|c|}
\hline Group & $\begin{array}{l}\text { No. } \\
\text { of mice }\end{array}$ & $\begin{array}{l}\text { Islet area } \\
\left(\mu \mathrm{m}^{2}\right)\end{array}$ & $\begin{array}{l}\text { Pancreas area } \\
\left(\mathrm{mm}^{2}\right)\end{array}$ & $\begin{array}{l}\text { Islet/pancreas } \\
\text { area }(\%)\end{array}$ & $\begin{array}{l}\text { No. of islets } \\
\text { examined } \\
\text { per pancreas }\end{array}$ & $\begin{array}{l}\text { No. of islets } \\
\text { measured }\end{array}$ & $\begin{array}{l}\text { Islet density } \\
\left(n / \mu \mathrm{m}^{2} \text { of }\right. \\
\text { pancreas })\end{array}$ \\
\hline \multicolumn{8}{|l|}{$\overline{\text { Adults }}$} \\
\hline $\begin{array}{l}\text { Betel + } \\
\text { IGT - }\end{array}$ & 6 & $\begin{array}{l}30046 \\
(1410-144300)\end{array}$ & $\begin{array}{l}25.46 \\
(7.47-43.4)\end{array}$ & $\begin{array}{l}1.028 \\
(0.06-1.7)\end{array}$ & $\begin{array}{l}15.89 \\
(3-14)\end{array}$ & 50 & $\begin{array}{l}0.40 \\
(0.13-0.92)\end{array}$ \\
\hline $\begin{array}{l}\text { Betel + BC + } \\
\text { IGT - }\end{array}$ & 5 & $\begin{array}{l}15911^{\mathrm{a}} \\
(11-33850)\end{array}$ & $\begin{array}{l}32.98 \\
(22.3-43.5)\end{array}$ & $\begin{array}{l}0.509 \\
(0.22-0.76)\end{array}$ & $\begin{array}{l}16.8 \\
(5-17)\end{array}$ & 53 & $\begin{array}{l}0.35 \\
(0.18-0.76)\end{array}$ \\
\hline $\begin{array}{l}\text { F1 offspring } \\
\text { Control }\end{array}$ & 9 & $\begin{array}{l}15240 \\
(453-253000)\end{array}$ & $\begin{array}{l}31.56 \\
(8.77-64.8)\end{array}$ & $\begin{array}{l}0.887 \\
(0.29-2.25)\end{array}$ & $\begin{array}{l}15.44 \\
(4-35)\end{array}$ & 143 & $\begin{array}{l}0.55 \\
(0.25-1.15)\end{array}$ \\
\hline $\begin{array}{l}\text { Mother Betel + } \\
\text { F1 IGT + }\end{array}$ & 9 & $\begin{array}{l}36331^{c} \\
(378-392000)\end{array}$ & $\begin{array}{l}30.94 \\
(19.6-69.2)\end{array}$ & $\begin{array}{l}1.618 \\
(0.019-4.12)\end{array}$ & $\begin{array}{l}10.6 \\
(2-30)\end{array}$ & 139 & $\begin{array}{l}0.47 \\
(0.050-0.81)\end{array}$ \\
\hline $\begin{array}{l}\text { Mother or father } \\
\text { Betel }+ \\
\text { F1 IGT - }\end{array}$ & 30 & $\begin{array}{l}25796^{\mathrm{b}} \\
(447-334000)\end{array}$ & $\begin{array}{l}37.02 \\
(16.2-39.2)\end{array}$ & $\begin{array}{l}0.835 \\
(0.56-5.43)\end{array}$ & $\begin{array}{l}17.67 \\
(2-26)\end{array}$ & 356 & $\begin{array}{l}0.33 \\
(0.12-0.74)\end{array}$ \\
\hline
\end{tabular}

${ }^{\mathrm{a}} p<0.01 ;{ }^{\mathrm{b}} p<0.001 ;{ }^{\mathrm{c}} p<0.0001$

Showing number of animals examined, mean values and ranges (min-max) of islet and pancreatic areas, islet/pancreatic area ra- tios (as \%), numbers of islets/pancreas per animal examined and per unit area of pancreas 

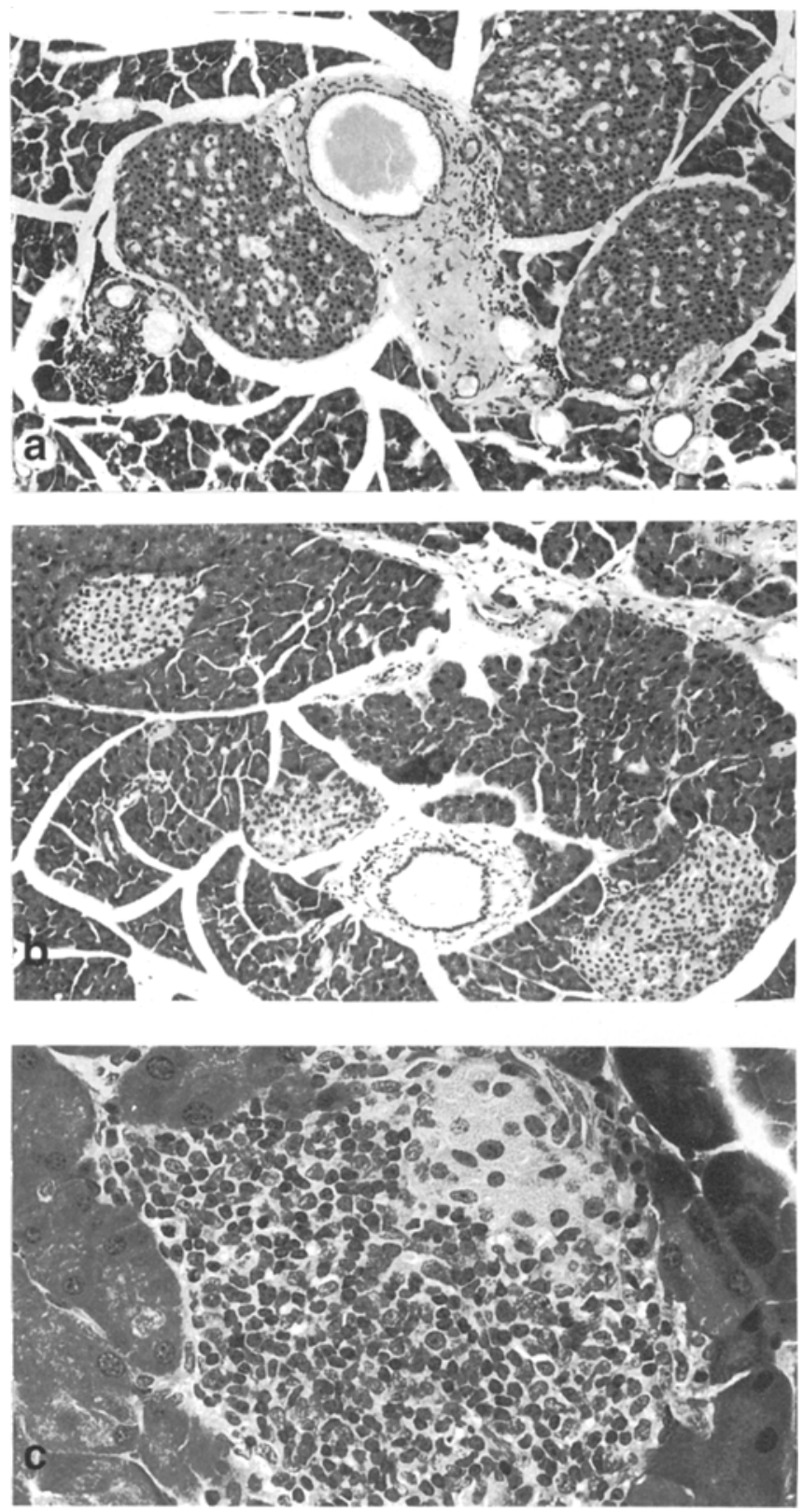

Fig. 2a-c. The islets of betel-fed CD1 mice with IGT (a) are enlarged compared to age-matched normally fed control CD1 mice (b). Insulitis (c) was present in one betel-fed CD1 mouse with impaired glucose tolerance. Haematoxylin and eosin stain. Magnification (a), (b) $\times 65$, (c) $\times 350$

moglycaemic, 1 of 14 male and 1 of 11 female offspring had IGT; moreover the mean 90-min plasma glucose levels of male progeny of any Group 1 betel-fed parent with IGT was significantly raised (mean $13.6 \mathrm{mmol} / \mathrm{l}$ ) compared to those of betel-fed but normoglycaemic parents (mean $8.77 \mathrm{mmol} / 1, p<0.01$ ). There was no difference in the corresponding means of female progeny (7.27 and $6.2 \mathrm{mmol} / \mathrm{l}$, respectively). The incidence of IGT in the offspring of control-fed Group 2 animals (Table 2) was nil but was significant $(p<0.005)$ for male and female offspring of matings of male or female betel-fed animals with control-fed animals. The overall incidence of IGT in F1 offspring of the various betel-fed parents in Groups 1 and 2 was significant $(p<0.005), 14$ of $60 \mathrm{in}$ males and 11 of $55 \mathrm{in}$ females with an SIR of 105.5 (95\% confidence limits 11.29-985.5). There were no progeny that survived to be weaned from matings between betel-fed adults when both had IGT. The important role of the betel-fed father even when normoglycaemic is shown by the appearance of IGT in progeny from matings with normal control females, and by the positive relationship found for the combined Group 1 and 2 F1 offspring 90-min glucose levels to paternal $(p<0.01)$, but not to maternal glycaemia. The incidence of IGT in litters of F2 offspring from betel-fed Group 1 grandparents is shown in Figure 1 which also shows that the level of IGT in F1 females did not appear to influence the incidence of IGT in the next (F2) generation. FourF3 litters descended from Group 1 betel-fed greatgrandparents were tested (in 2 of the 3 litters 1 greatgrandmother and one grandfather had IGT) and 1 of 16 males and 0 of 20 females had developed IGT. The mean 90-min plasma glucose levels were 9.5 (7.15-17.1) and $6.5(5.2-8.4)$ in males and females, respectively. Table 3 shows the incidence of IGT in the various groups studied. Examination of the pancreas of betel-fed Group 2 adult mice (Table 4) revealed hyperplasia of some islets in normoglycaemic animals and in those with IGT, but without a significant increase in mean areas. No hyperplasia was found in animals fed betel with $\beta$ carotene. The mean area of the islets was larger than normal (i.e. than in $\mathrm{F} 1$ offspring control animals), in all Group 2 F1 offspring with a betel-fed parent. The largest islets were found in those whose mothers had been betel fed and themselves had IGT. The least enlarged islets were the offspring without IGT, one of whose parents had been betel fed; whilst the offspring with IGT whose fathers had been betel fed had islets of intermediate size. There were no differences in islet number/unit pancreatic area or in islet/pancreatic area ratios between these groups of animals. Mean islet areas per gramme body weight were increased in line with islet areas in betel-fed animals and their offspring. Minor increases in periductal lymphocytes near the islets were seen in glucose-intolerant betel-fed adult mice. Marked lymphocytic infiltration was seen in and around the islets of one Group 1 offspring with IGT though the islets of all other such offspring appeared similar to those of betel-fed adult mice with IGT (Fig. 2).

\section{Discussion}

This study demonstrates that feeding betel nut to young adult mice can induce lasting glucose intolerance. The incidence of IGT was greater, both in adults and their subsequent offspring, than that seen in mice fed Icelandic smoked cured mutton or its nitrosamines [9], and affected animals were well built and healthy. 
Diabetogenic nitroso-compounds can induce Type 1 or Type 2 diabetes according to dose [7,8]. The IGT produced by betel feeding in the present study appears to be non-insulin-dependent. The increased islet size found in betel-fed mice with IGT and their offspring is similar to the changes found by Okamoto et al. [14] after partial pancreatectomy or exposure to islet toxins with resultant activation of the REG gene, and islets seem not to have been lost but to have hypertrophied at the expense of acinar tissue, though in the absence of weights or volumes for the whole gland this remains speculative. Individual susceptibility to the diabetogenic agent STZ appears to depend on MHC type, (class $1 \mathrm{~A}, 1 \mathrm{E}$ and $1 \mathrm{~J}$ ) [15, 16], and similar factors may determine betel-nut diabetogenicity.

The present study shows that the transmission of significant glucose intolerance to offspring was not a simple effect of maternal hyperglycaemia during gestation since F1 glycaemia related to paternal but not maternal glycaemia and IGT developed in some offspring of betel-fed male mice mated with betel-fed normoglycaemic females or with normal control female mice. IGT was found in $11 \%$ of the $\mathrm{F} 2$ generation derived from betel-fed grandparents when neither parent was glucose intolerant. The mechanism by which $\mathrm{N}$ nitroso compounds such as STZ cause diabetes has been suggested to be the binding of a glucose ring-like moiety in the molecule to beta-cell glucose receptors, leading to DNA damage $[14,17]$. Betel-nut nitrosamines include similar structures [18]. The induction of IGT in progeny of nitrosamine-treated animals is unlikely to be due to placental transfer, since clearance of nitrosamines from tissues takes less than $24 \mathrm{~h}$, though it is slower from the testes [9]. In addition mating began 2 weeks after completion of test feeding and second F1 litters contained diabetic offspring from Group 2 betel-fed adults, as reported with other nitrosamine-induced diabetes [19]. The major abnormalities reported in the heads of spermatozoa 30 days after completion of 5 days administration of pan masala (a betel-nut containing snack) to adult mice [20], and the damage to chromosomes in circulating lymphocytes in man and mouse following betel consumption suggests a nuclear mutation should be considered [21], though the more rapid rates of mitochondrial mutation would provide a mechanism for the marked changes in disease incidence between generations [22]. Epidemiological studies of risk markers for diabetes in relation to dietary factors including betel chewing carried out in East London are being analysed in relation to glycaemia (B.J. Boucher, N. Mannan, unpublished observations). Simple oral supplements of $\beta$-carotene or eating betel nut in piper betel vine-leaf wrapped 'quids' (leaves shown to contain compounds suggestive of cartainoids on preliminary spectrophotometry) reduces both DNA damage and the incidence of mouth cancer in man $[11,18]$. These observations together with the preliminary finding that islets in animals fed betel nut with $\beta$-carotene were smaller rather than larger, and recent work showing that $\beta$-carotene is the most effective antidote to the mutagenic effect of dilute aqueous extracts of betel nut on mouse and human tissues in culture (D.N.Wheatley, J.M.Stowers, unpublished observations) suggest that strategies could be found to reduce the diabetogenicity of nitrosated compounds relevant to man, as demonstrated in experimental animals [14]. Further feeding studies with added $\beta$-carotene are therefore in progress. Betel nut has been chewed for hundreds of years, and is currently used by $10 \%$ of the world's population [23], which makes the suggestion that it could be diabetogenic of potential practical importance.

Acknowledgements. The authors thank Dr. J. R. A. Pollock of Pollock \& Pool PLC for information and helpful discussion on betel-nut nitrosamines and Dr. C. Mitchell, St. Thomas' Hospital for qualitative analysis of Piper betel vine leaves for $\beta$-carotenoids. We also thank the staff of the Animal House of the Medical School of Aberdeen University and Mr. R. Rountree and his staff at The London Hospital Medical College for invaluable technical assistance, the Research Fund of the Diabetic Service, Aberdeen and The Royal London Hospital Special Trustees for financial support, Dr. C. L. Brown for the histology of Group 2 mouse pancreas, and Dr S. Greenwald for training on the Magiscanner and for analysis of the measurements for which it was used.

\section{References}

1. McKeigue PH, Marmot MG, Syndercombe Court YD (1988) Diabetes, hyperinsulinaemia, and coronary risk factors in Bangladeshis in East London. Br Heart J 60: 390-396

2. Mather H, Keen H (1985) The Southall Diabetes Survey; prevalence of known diabetes in Asians and Europeans. BMJ 291: 1081-1084

3. Zimmet P, Taylor P, Ram P et al. (1983) Prevalence of diabetes and impaired glucose tolerance in the bi-racial (Melanesian and Indian) population of Fiji: a rural-urban comparison. Am J Epidem 118: 673-688

4. Ramachandran A, Jali MV, Mohan V et al. (1988) High prevalence of diabetes in an urban population in South India. BMJ 297:587-590

5. Chauduri R, Samanta A, Burden AC (1989) Prevalence of insulin-taking diabetes mellitus; differences between white and (Indian) Asians in the UK. Diabetic Med 6 [Suppl 2]: 47: 21 a (Abstract)

6. Marmot MG, Adelstein AM, Bulusu L (1980) Causes of death by country of birth. (Survey on medical and population subjects). Office of Population Census and Surveys. HMSO No 47. London, United Kingdom

7. Bonner-Weir S, Leahy JL, Weir GC (1988) Induced rat models of non-insulin dependent diabetes. In: Shafrir E, Renold AE (eds) Lessons from animal diabetes 2: Frontiers in diabetes research. Libbey, London

8. Karam JH, Lewitt PA, Young CW et al. (1980) Insulinopenic diabetes after Rodenticide (Vacor) ingestion. Diabetes 29 : 971-978

9. Helgason T, Ewen SWB, Jaffrey B et al. (1984) N-nitrosamines in smoked meats and their relation to diabetes. IARC Sci Pub 57: 911-920

10. Boucher BJ, Ewen SWB, Stowers JM (1991) Betel nut (Areca catechu) consumption as an aetiological agent for 
diabetes mellitus; studies in CD1 mice and their offspring. Diabetic Med 8 [Suppl 1]: P4 (Abstract)

11. Stitch HF, Rosin MP, Hornby AP et al. (1988) Remission of oral leukoplakias and micronuclei in tobacco and betel quid chewers treated with beta-carotene and with beta carotene plus vitamin A. Int J Cancer 42: 195-199

12. Aherne WA, Dunnill MS (1980) Morphometry. Churchill Livingstone

13. Snedecor GW, Cochrane WG (1968) Statistical methods. Iowa State University Press, Iowa, Iowa. USA

14. Okamoto H, Yamamoto H, Takasawa S et al. (1988) Molecular mechanism of degenerations: oncogenesis and regeneration of pancreatic $\beta$-cells of islets of Langerhans. In: Shafrir E, Renold AE (eds) Frontiers in diabetes research: lessons from animal diabetes. John Libby \& Co., London, pp 149-157

15. Kiesel U, Oschilewski M, Taniguchi M, Kolb H (1989) Modulation of low-dose streptozotocin-induced diabetes in mice by administration of antibodies to IA, IE and IL determinants. Diabetologiy 32:173-176

16. Tanaka SI, Nakajima AS, Inoue S et al. (1990) Genetic control by Ia subregions on $\mathrm{H}-2$ complex of incidence of streptozotocin induced autoimmune diabetes in mice. Diabetes 39: 1298-1304
17. Pour PM, Raha CR (1981) Pancreatic carcinogenic effect of nitrosobis(2-oxybutyl)amine and $\mathrm{N}$-nitroso(2-oxybutyl)(2oxopropy)amine in Syrian Hamster. Cancer Letters 12: 223 229

18. Prokopczyk BP, Rivenson A, Bertinato et al. (1987) 3(methylnitrosamino) propio-nitrile: occurrence in saliva of betel-chewers, carcinogenicity and DNA methylation in F344 rats. Cancer Res 47: 467-471

19. Stowers JM, Ewen SWB (1991) Possible dietary factors in the induction of diabetes and its inheritance in man with studies in mice. Proc Nutr Soc 50: 287-298

20. Mukherjee A, Chakrabarti J, Chakrabarti A, Banerjee T, Sarma A (1991) Effect of 'Pas Masala' on the germ cells of male mice. Cancer Letts. 58: 161-165

21. Wary KW, Sharan RN (1988) Aqueous extract of betel-nut of North East India induces DNA-strand breaks and enhances rate of cell proliferation in vitro. $\mathrm{J}$ Cancer Res Clin Oncol 114: 579-582

22. Gerbitz K-D (1992) Does the mitochondrial DNA play a role in the pathogenesis of diabetes? Diabetologia 35: 1181-1186

23. Encyclopaedia Britannica 1974 (c1977); 'Areca catechu' (Betel-nut) 